\title{
Exploitation of natural food sources by two sympatric, invasive suspension-feeders: Crassostrea gigas and Crepidula fornicata
}

\author{
Priscilla Decottignies ${ }^{1, *}$, Peter G. Beninger ${ }^{1}$, Yves Rincé ${ }^{1}$, Richard J. Robins ${ }^{2}$, \\ Pascal Riera ${ }^{3}$
}

${ }^{1}$ Université de Nantes, Laboratoire de Biologie Marine, UPRES EA 2663, Faculté des Sciences et des Techniques, 2 Rue de la Houssinière, Nantes 44322, France

${ }^{2}$ Université de Nantes, Laboratoire d'Analyse Isotopique et Électrochimique des Métabolismes Faculté des Sciences et des Techniques, 2 Rue de la Houssinière, Nantes 44322, France

${ }^{3}$ Université de Paris 6, Centre d'Etudes d'Océanographie et de Biologie Marine, UMR 7127, Station Biologique de Roscoff, Place Georges-Teissier, Roscoff 29682, France

\begin{abstract}
The natural diets of the introduced suspension-feeders Crassostrea gigas (Thunberg) and Crepidula fornicata (L.) were determined at a mid-latitudinal oyster-farming site within their European range (Bourgneuf Bay, France). Carbon and nitrogen stable isotope deviations of Pacific oysters and slipper limpets were compared with potential food sources on 3 sampling dates (March, July and November 2003). Four end-members were assimilated by the 2 species: $\mathrm{C}_{3}$ angiosperm detritus, macroalgae- $\mathrm{C}_{4}$ plant detritus, marine phytoplankton and benthic diatoms. Given the lack of source digestibility data for suspension-feeders, and these 2 species in particular, extreme feasible combinations of relative end-member contributions were calculated according to 2 assimilation scenarios, using either IsoSource software or a concentration-dependent model. For both Crassostrea gigas and Crepidula fornicata, benthic and planktonic microalgae dominated diets on the 3 sampling dates. Planktonic microalgae were ingested in greater proportions than benthic species in July and November; however, benthic diatoms also formed a constant and significant part of diets in these months, and were consumed in greater proportions than planktonic species in March. Plant (especially macroalgal) detritus played a major role in the diets of the 2 suspension-feeders, notably in March 2003 when it became the principal ingested source. The substantial contribution of plant detritus to the natural diets of these species has not previously been reported. Although Crassostrea gigas and Crepidula fornicata showed significantly different isotopic deviations in March and July 2003, trophic niches of Crassostrea gigas and Crepidula fornicata overlapped on all 3 sampling dates, with a greater ingestion of identical sources in November. These 2 invasive species could therefore be trophic competitors in the context of end-member supply limitation. Contrary to previous analyses conducted on these 2 species in Europe, this study reports significant dietary overlap. Ecosystemspecific diet studies of invasive species are thus necessary in order to understand trophic overlap/ competition as a function of the diversity and availability of local food sources.
\end{abstract}

KEY WORDS: Slipper limpet $\cdot$ Oyster $\cdot$ Diet $\cdot$ Stable isotopes $\cdot$ IsoSource $\cdot \delta^{13} \mathrm{C} \cdot \delta^{15} \mathrm{~N}$ Resale or republication not permitted without written consent of the publisher

\section{INTRODUCTION}

The ecological and evolutionary consequences of invasive species (sensu Davis \& Thompson 2000) within coastal marine systems have only become the focus of scientific investigation relatively recently (see Grosholz 2002). To date, the approach has generally been to study the effects of invasive species relative to indigenous communities. European oyster rearing sites represent a special situation, because an accidentally 
introduced suspension-feeder Crepidula fornicata L. is sympatric with the intentionally established species Crassostrea gigas Thunberg, and trophic competition between the two is suspected (Blanchard 1997). Moreover, C. gigas shows signs of proliferation outside of oyster rearing sites, making it both a 'desired' species within farms and a 'pest' species (Ruesink et al. 2005).

Despite long-standing concerns over the potential effects of the slipper limpet Crepidula fornicata on indigenous communities, there was no research interest in this species until quite recently, and this was largely motivated by problems encountered in regions of high density where shellfish are also exploited, in particular the introduced Pacific oyster Crassostrea gigas. Multiple ecosystem impacts have since been documented: sediment transformation (Ehrhold et al. 1998), macrozoobenthos modifications (de Montaudouin et al. 1999, Le Pape et al. 2004) and changes in food web structure (Chauvaud et al. 2000).

Concerns over the impact of slipper limpets on oyster production were reinforced by observations of simultaneous larval presence and juvenile recruitment (Cole \& Hancock 1956), oyster larvae consumption (Korringa 1951), feeding mode and qualitative analyses of stomach contents (Orton 1912). More recent studies (e.g. de Montaudouin et al. 1999, Riera et al. 2002) raised the possibility that a partial overlap of trophic niches exists, and stressed the importance of taking into account the specific trophic dynamics of each ecosystem occupied by both Crepidula fornicata and Crassostrea gigas. Furthermore, although both suspensionfeeders were found to have equivalent biomass and the same filtration impact in Bourgneuf Bay, France (Barillé et al. 2006), it is necessary to determine the particle types consumed by each species in order to estimate the eventual degree of trophic competition.

Apart from early qualitative studies (Orton 1912), the diets of sympatric cultivated oysters and slipper limpets are largely unknown. Currently, multiple natural stable isotope analyses are widely used in food web studies, notably to determine the food sources of suspension-feeders (e.g. Kang et al. 1999, Page \& Lastra 2003), which are exposed to seasonal variations in food availability. Such an approach was successfully used to compare the nutritional resources of Crepidula fornicata and Crassostrea gigas in a Northern European coastal ecosystem (Riera et al. 2002).

Here we present a stable isotope study that determined the sources of carbon and nitrogen assimilated by Crepidula fornicata and Crassostrea gigas on 3 seasonal sampling dates in a high-turbidity oysterfarming site, which is characterized by decreasing yields concomitant with slipper limpet proliferation (Barillé-Boyer et al. 1997). The site chosen was Bourgneuf Bay, a mid-latitudinal point in the European distribution of these species.

\section{MATERIALS AND METHODS}

Study area. The 34000 ha of Bourgneuf Bay, located south of the Loire Estuary on the French Atlantic coast (Fig. 1), is comprised of 10000 ha of intertidal area (mean tidal range: $4 \mathrm{~m}$ ). The large northern opening into the Atlantic Ocean allows considerable mixing of bay and oceanic waters, whereas the southern narrows restricts water exchange. Similarly, the deeper (mean: $10 \mathrm{~m}$ ) northern part of the bay is strongly influenced by W and SW winds, swells and gyratory currents. These hydrodynamic characteristics transport resuspended sediment from mudflats, resulting in particularly high turbidity in the northern reaches of the Bay (annual mean: $150 \mathrm{mg}$ $\mathrm{I}^{-1}$; Barillé-Boyer et al. 1997). The bay is also variably affected by the Loire estuary, depending on discharge rates and prevailing winds.

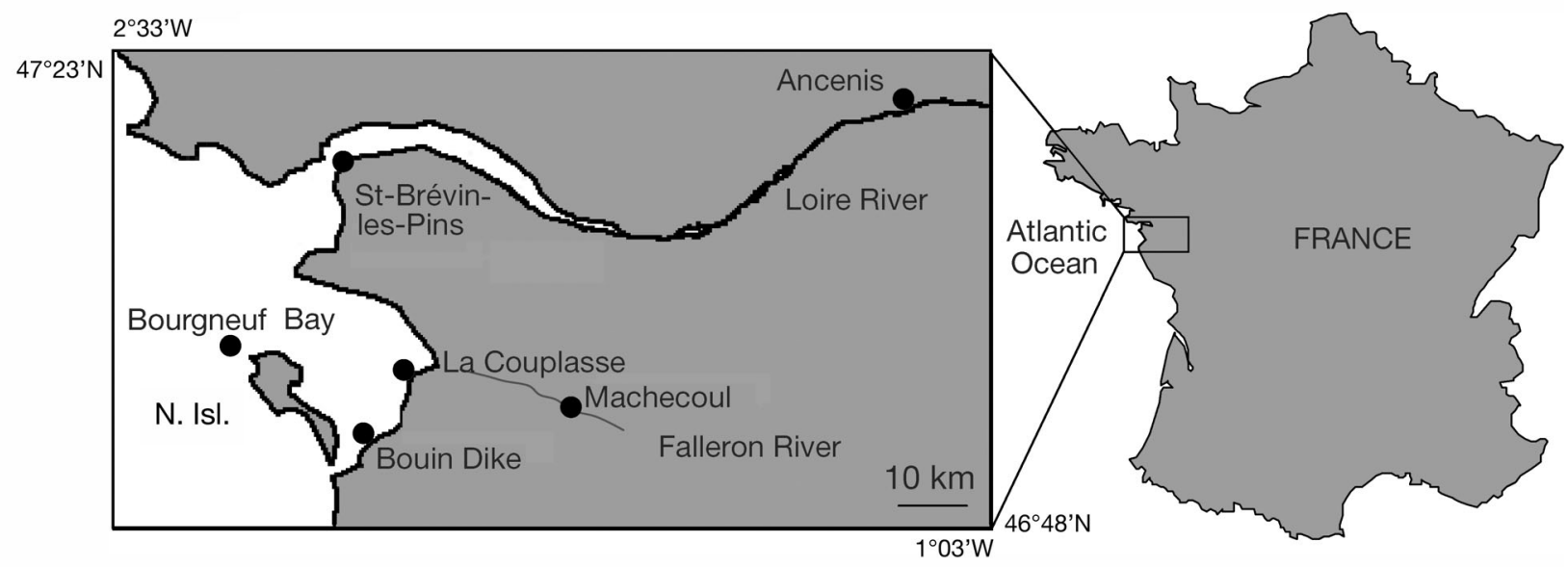

Fig. 1. Location of sampling sites (-) in Bourgneuf Bay, Loire Estuary and River. N. Isl.: Noirmoutier Island 
The sampling site for oysters and slipper limpets was an oyster farm at La Couplasse (Fig. 1), where a high biomass of slipper limpets Crepidula fornicata (L. Barillé pers. comm.) is located directly adjacent to cultured oyster Crassostrea gigas stocks. This area is characterized by high residence times, which increase the influence of freshwater input from the Falleron River (Barillé-Boyer et al. 1997), and by an important diatomdominated microphytobenthos proliferation on mudflats, which covers 19 to $25 \%$ of the surface (Méléder et al. 2003).

Sampling plan. Five Pacific oysters (mean shell length \pm SD: $9.7 \pm 1.4 \mathrm{~cm}$ ) and 5 slipper limpets (mean linear shell length \pm SD: $3.2 \pm 0.5 \mathrm{~cm}$ ) were collected at low spring tide at La Couplasse in March, July and November 2003. All possible sources of organic matter available to suspension-feeders at this site were collected concomitantly: freshwater, brackish water, oceanic microplankton, microphytobenthos, macroalgal and higher plant detritus.

Sub-surface oceanic water samples were taken during sampling cruises off Noirmoutier Island. Brackish water was collected at the Bouin seawall and from the Loire estuary at St-Brévin-les-Pins. Freshwater was sampled upriver from the Loire estuary at Ancenis, and from the Falleron River at Machecoul (Fig. 1); 201 of each water sample were collected in plastic containers.

Microphytobenthos was sampled at La Couplasse. The upper $5 \mathrm{~mm}$ of a $1 \mathrm{~m}^{2}$ mudflat area with dense brown microphytobenthic covering was collected with a spatula. Macroalgal thalli and marine angiosperm leaves were collected at La Couplasse and Bouin, and terrestrial angiosperm leaves at Ancenis and Machecoul (Fig. 1). The selected plant species were common at the different sampling sites: Enteromorpha sp., Fucus serratus and Fucus vesiculosus represented macroalgae; Halimione portulacoides, Salicornia sp. and Spartina sp. represented marine angiosperms; and Alnus sp., Populus sp. and Robinia pseudoacacia represented terrestrial angiosperms. As Alnus sp. and Populus sp. leaves were not present on the March sampling date, data for these potential food sources were limited to June and November.

Sample preparation. Sampled individuals were cleaned of epibionts in the laboratory and gut contents were purged in $0.2 \mu \mathrm{m}$ filtered seawater from the sampling site for 12 to $24 \mathrm{~h}$. The individuals were killed by freezing, and then soft tissues were separated from the shells, bathed for 1 to $2 \mathrm{~min}$ in $1 \mathrm{M} \mathrm{HCl}$ in order to eliminate trace shell carbonates, rinsed in Milli-Q ultrapure water and then homogenized with an Ultra-Turrax blender. Samples were stored at $-80^{\circ} \mathrm{C}$, freeze-dried, and reduced to a powder with a mortar and pestle prior to analysis.
Triplicate water samples were vacuum-filtered onto $47 \mathrm{~mm}$ or $25 \mathrm{~mm} \mathrm{GF/F}$ pre-combusted $\left(500^{\circ} \mathrm{C}, 4 \mathrm{~h}\right)$ filters until clogged. The retentate was acidified with several drops of $1 \mathrm{M} \mathrm{HCl}$ in order to remove carbonates, rinsed with ultrapure water, and stored at $-80^{\circ} \mathrm{C}$ prior to freeze-drying.

Benthic microalgae, mainly motile diatoms, were extracted as per Riera \& Richard (1996). The sediment sample was spread onto a tray to a thickness of about $1 \mathrm{~cm}$, covered with a $63 \mu \mathrm{m}$ mesh nylon net, and then with a thin layer of pre-combusted $\left(500^{\circ} \mathrm{C}, 4 \mathrm{~h}\right)$ fine (150 to $300 \mu \mathrm{m}$ ) silicious sand. The size of the mesh was chosen to include all migrating pennate forms, whose widths are smaller than the mesh size. The tray contents were regularly wetted with vaporized $(0.2 \mu \mathrm{m}$ filtered) seawater from the sample site and illuminated until the following diurnal tide, because benthic diatoms maintain an endogenous rhythm (Mitbavkar \& Anil 2004). After migration of the diatoms to the sand layer, visible as a brownish coloration, the superficial layer was then carefully removed with a spatula, placed in a $63 \mu \mathrm{m}$ mesh screen and rinsed with filtered seawater. The resulting liquid was then processed as above for water samples.

When present, epibionts were discarded from plant samples, which were then acidified and treated as above for mollusks.

Stable isotope and \% organic $\mathbf{C}$ and N. Duplicate powdered samples or pieces of filter were sealed in ultraclean tin capsules and analyzed for nitrogen and carbon content (\% dry weight) and composition $\left(\delta^{13} \mathrm{C}\right.$ and $\delta^{15} \mathrm{~N}$ ) using a Carlo-Erba NA 2100 elemental analyzer coupled (via a Thermo Finnigan CONFLO II interface) with a Thermo Finnigan Delta S mass spectrometer. Carbon and nitrogen isotope compositions were expressed in standard delta notations (\%o deviations from a reference): $\delta X=\left[\left(R_{\text {sample }} \times R_{\text {reference }}{ }^{-1}\right)-1\right] \times$ $10^{3}$, where $X$ is either ${ }^{13} \mathrm{C}$ or ${ }^{15} \mathrm{~N}$ and $R$ is the corresponding ${ }^{13} \mathrm{C}:{ }^{12} \mathrm{C}$ or ${ }^{15} \mathrm{~N}:{ }^{14} \mathrm{~N}$ ratio. Results were referred to Vienna Pee Dee Belemnite for carbon and to atmospheric $\mathrm{N}_{2}$ for nitrogen. A regularly calibrated working reference (glutamic acid) was run every 11 samples. The SD of $200 \delta^{13} \mathrm{C}$ and $\delta^{15} \mathrm{~N}$ working reference measurements was 0.2 and $0.4 \%$ respectively. Isotope readings were validated when the difference between duplicate capsules of the same sample was less than 0.4 and $0.5 \%$ for carbon and nitrogen deviations respectively; otherwise, samples were analyzed a second time.

As described above, microphytobenthos and marine particulate organic matter (POM) were obtained by GF/F filtration. Insufficient material was collected to allow removal from filters without including glass fibers. Consequently, it was not possible to calculate the carbon and nitrogen content of the masses sealed 
in capsules; we therefore calculated mean C:N ratios and assigned $\% \mathrm{C}$ and $\% \mathrm{~N}$ content according to data from fiber-free samples available in the literature (Abed-Navandi \& Dworschak 2005).

Statistics. R freeware (R Development Core Team 2005) was used for all statistical computing. Data normality was verified using the Shapiro-Wilks test, and heteroscedasticity checked with either an F-test (2 samples) or a Bartlett's test ( $>2$ samples) before choosing parametric or non-parametric statistical analysis.

For each source, isotope composition according to sampling date was analysed with a 1-way parametric or non-parametric (Kruskal-Wallis) ANOVA as appropriate. As data for Alnus sp. and Populus sp. were only available from the June and November samples, their carbon and nitrogen isotope deviations were tested using a Welch 2-sample $t$-test or Wilcoxon rank sum test, as appropriate. Two-way ANOVAs, followed by Tukey's honestly significant difference (HSD) test, were performed to compare oyster and slipper limpet isotope compositions, with sampling dates and species as factors.

Dietary analysis. A certain amount of debate has been generated concerning the enrichment factors to be used in diet calculations (e.g. Gannes et al. 1997, Post 2002). The most widely-used values, specifically recommended since the inception of the stable isotope technique, are 1 and $3.4 \%$ for carbon and nitrogen deviations respectively (DeNiro \& Epstein 1978, Post 2002). These enrichment factors have recently been corroborated for bivalve soft tissues (Yokoyama et al. 2005). Alternate values of 0.5 and $2 \%$ were proposed (McCutchan et al. 2003), and we also completed our calculations using these values; however, as this did not affect our main results or conclusions, the more widely-accepted values of 1 and $3.4 \%$ were maintained in the present study.

After determination of the food sources implicated in Crepidula fornicata and Crassostrea gigas diets (see 'Results'), isotopic values were combined a priori to characterize source types according to functional considerations, e.g. the $\mathrm{C}_{3}$ saltmarsh angiosperm group. The squared nearest neighbor distances $\left(\mathrm{NND}^{2}\right)$ (Lubetkin \& Simenstad 2004) were then calculated to determine whether the isotopic deviations of these source types were distinct or required pooling. The number of source types ( $>n$ isotopes +1$)$ precluded the use of linear mixing models, and hence calculation of the exact proportional contributions of each end-member. We therefore used IsoSource 1.2 software (Phillips \& Gregg 2003) to estimate the ranges of biomass contributions of each end-member to the oyster and slipper limpet diets. We also wrote a Scilab 3.1.1 program (INRIA, ENPC) to estimate elemental concentrationweighted biomasses (Newsome et al. 2004). These models determined all feasible end-member combinations by successively incrementing each source proportion by $1 \%$ from 0 to $100 \%$. A combination was considered feasible if the calculated mixture composition was equal to the measured composition or within a mass balance tolerance of $0.2 \%$. This tolerance greatly exceeded the recommended minimum $(0.5 \times$ source increment $\times$ maximum difference between sources, i.e. $0.09 \%$ for our data; Phillips \& Gregg 2003), given the observed sample variability.

The range of feasible solutions was used in all subsequent representations (frequency distributions and bivariate graph matrices) of feasible dietary contributions. However, means were used in calculations of trophic niche parameters, because single values are required and it was not possible to associate oyster and slipper limpet combinations. Niche breadths of Crassostrea gigas and Crepidula fornicata were compared using Levins' standardized measure (Krebs 1999)

$$
\begin{aligned}
& B_{\mathrm{A}}=\frac{B-1}{\mathrm{n}-1} \\
& B=\frac{1}{\sum_{1}^{\mathrm{n}} p_{j}{ }^{2}}
\end{aligned}
$$

where $B_{\mathrm{A}}$ is Levins' standardized niche breadth, $B$ is Levins' measure of niche breadth, $\mathrm{n}$ is the number of possible source types and $p_{j}$ is the fraction of food category $j$ in the diet (mean of IsoSource simulations).

Niche overlap (Krebs 1999) between Crassostrea gigas and Crepidula fornicata was determined as Pianka's measure

$$
O_{j k}=\frac{\sum_{i}^{\mathrm{n}} p_{i j} p_{i k}}{\sqrt{\sum_{i}^{\mathrm{n}} p_{i j}^{2}} \sum_{i}^{\mathrm{n}} p_{i k}^{2}}
$$

where $O_{j k}$ is Pianka's measure of niche overlap between species $j$ and $k$, and $p_{i j}$ and $p_{i k}$ are the proportions of food source $i$ (mean of IsoSource simulations) of the total sources used by species $j$ and $k$.

\section{RESULTS}

\section{Source $\delta^{13} \mathrm{C}$ and $\delta^{15} \mathrm{~N}$}

Mean isotopic deviations of the source samples and results of statistical tests among dates are presented in Tables $1 \& 2$ respectively. The $\delta^{13} \mathrm{C}$ deviations of river freshwater POM of the Loire and Falleron were similar at approx. $-30 \%$, which is characteristic of 
terrestrial inputs. Estuarine POM carbon isotope values (approx. -25\%) were intermediate between freshwater POM and open sea phytoplankton (approx. $-22 \%$ ). The bay POM $\delta^{13} \mathrm{C}$ was clearly marine, with values close to $-23 \%$. The most depleted carbon deviations of POM were encountered in March 2003, and the most-enriched in November (in most cases). Although the origin of this trend is not clear, similar results were reported by Sará et al. (2003), one of the few marine studies dealing with seasonal changes.

Alnus sp., Fraxinus sp., Populus sp. and Robinia pseudoacacia displayed carbon deviations between -26 and $-29 \%$, typical of terrestrial $\mathrm{C}_{3}$ angiosperms. Spartina sp. presented characteristic $\mathrm{C}_{4}$ $\delta^{13} \mathrm{C}$ values (approx. $-14 \%$ ), which were ${ }^{13} \mathrm{C}$-enriched relative to the two $\mathrm{C}_{3}$ marsh angiosperms, Salicornia sp. and Halimione portulacoides that presented carbon isotope deviations of about $-26 \%$. Macroalgae also exhibited typical carbon values (approx. $-16 \%$ ). In marine angiosperms and macroalgae, the most ${ }^{13} \mathrm{C}$ enriched compositions were measured in March 2003, especially for Enteromorpha sp., which presented an extremely high $\delta^{13} \mathrm{C}$ value $(-6.4 \%)$. The majority of $\delta^{13} \mathrm{C}$ values, as well as $\delta^{15} \mathrm{~N}$ ( 7 to $11 \%$ ), were within the ranges measured in the same species elsewhere, e.g. in France and in the Netherlands (Riera et al. 1996, 2002).

Saltmarsh plant (genera Halimione, Salicornia and Spartina) nitrogen deviations (8.3 to $10.8 \%$ and one outlier of $17.3 \%$; Table 1) were relatively ${ }^{15} \mathrm{~N}$ enriched compared with previous studies conducted in France or elsewhere, with values of 3 to $9 \%$ (e.g. Currin et al. 1995, Créach et al. 1997). This could be related to the incorporation of ${ }^{15} \mathrm{~N}$-rich ammonium and nitrate either from anthropogenic inputs or more probably from nitrification or denitrification processes in marsh sediments (Wada \& Hattori 1991).

Benthic diatom $\delta^{13} \mathrm{C}$ and $\delta^{15} \mathrm{~N}$ values were within the ranges previously measured in Oosterschelde (The Netherlands) and in Marennes-Oléron Bay (France) (-14.5 to $-11.3 \%$ and 4.6 to $6.6 \%$ respectively; Riera et al. 1996, 2002).

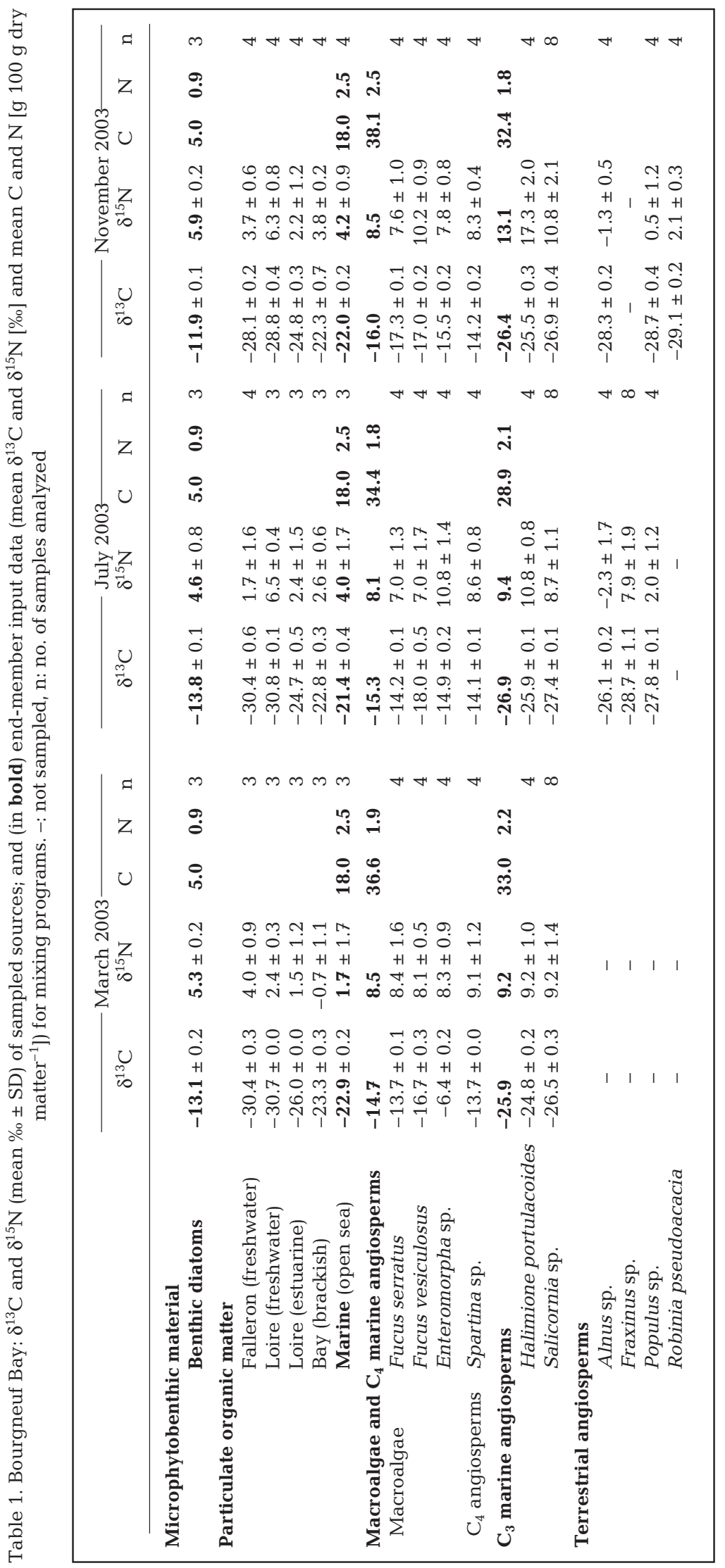


Table 2. Statistical tests of differences in $\delta^{13} \mathrm{C}$ and $\delta^{15} \mathrm{~N}$ values of sampled sources among months. For 2-way ANOVAs, degrees of freedom (df) between and within groups (= error or residual) are indicated by the first and second number respectively. Test statistics are values of $F, \chi^{2}$, $W$ and $t$ for ANOVAs, Kruskal-Wallis ANOVAs (KW), Wilcoxon tests $(\mathrm{W})$ and $t$-tests respectively. MS: mean squares. ${ }^{*}: \mathrm{p} \leq 0.05,{ }^{* *}: \mathrm{p} \leq 0.01$, ${ }^{* * *}: \mathrm{p} \leq 0.001$, ns: not significant

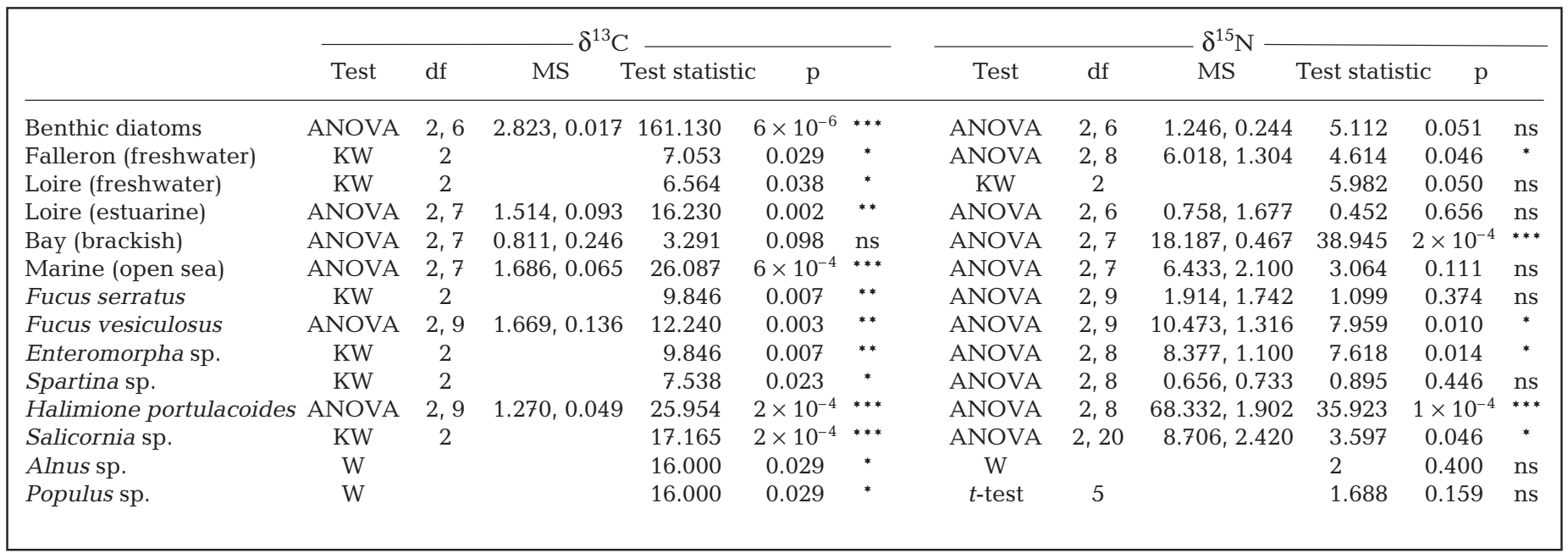

\section{Stable isotope deviations of oysters and slipper limpets}

Compared with the only previously recorded values of Crepidula fornicata (Riera et al. 2002), our results (Figs. 2 \& 7) are depleted in both carbon and nitrogen heavy isotopes by about $1 \%$. However, the deviations measured in the present study for Crassostrea gigas are within the ranges previously reported in the more extensive literature for this species (e.g. Riera 1998, Hsieh et al. 2000).

Two-way ANOVAs revealed significant differences between species for carbon and nitrogen deviations (df $=1, F=22.93, \mathrm{p} \leq 0.001$ and $F=6.872, \mathrm{p}=0.015$ respectively). Significant ${ }^{13} \mathrm{C}$-enrichment in slipper limpets (approx. 0.9\%) relative to values of oysters was observed in March and July 2003 (Tukey's HSD: p = 0.007 and $p=0.002$ respectively). Nitrogen deviations of oysters were significantly higher (approx. 1.1\%o) than those of slipper limpets in March 2003 (Tukey's HSD: $p<0.001$ ). No significant differences were observed in November samples (Tukey's HSD: $\mathrm{p}=$ 0.101 for $\delta^{13} C_{i} p=0.552$ for $\delta^{15} \mathrm{~N}$ ).

Although carbon deviations of Crepidula fornicata tissues did not differ significantly among the 3 sampling dates (2-way ANOVA: $\mathrm{df}=2, F=2.829, \mathrm{p}=0.079$; Tukey's HSD: $\mathrm{p}>0.05)$, the nitrogen deviations were significantly different (2-way ANOVA: $d f=2, F=$ $37.904, \mathrm{p} \leq 0.001$ ), with a ${ }^{15} \mathrm{~N}$ depletion of approx. $0.8 \%$ in November compared with March (Tukey's HSD: $\mathrm{p}=$ 0.021). The $\delta^{15} \mathrm{~N}$ values of oysters sampled in March were also significantly higher relative to July and November (approx. 2 and 1.7\% respectively; 2-way
ANOVA: $\mathrm{df}=2, F=37.904, \mathrm{p} \leq 0.001$; Tukey's HSD: $\mathrm{p}<$ 0.001). There was no significant difference in carbon deviations of Crassostrea gigas among the 3 sampling dates (2-way ANOVA: df $=2, F=2.829, p=0.079$; Tukey's HSD: $\mathrm{p}>0.05)$.

\section{Determination of Crepidula fornicata and Cras- sostrea gigas food sources}

Dual plot graphs of $\delta^{15} \mathrm{~N}$ versus $\delta^{13} \mathrm{C}$ (Fig. 2) allowed us to determine the food sources of Crassostrea gigas and Crepidula fornicata. On the 3 sampling dates, calculated diets had values of -19.5 to $-18.3 \%$ carbon and 5.4 to $7.4 \%$ nitrogen.

Nearshore POM is a complex mixture of marine phytoplankton, plant organic detritus and various other components (Heip et al. 1995); owing to the heterogeneous nature of such POM, it was thus not possible to include Bourgneuf Bay POM as a dietary component. However, since the bay isotopic composition was clearly not influenced by the continental Loire and Falleron discharges (in contrast to estuarine POM), we could exclude freshwater seston and terrestrial plants from the diets.

The isotopic values of the various source diet components assimilated by oysters and slipper limpets in Bourgneuf Bay (i.e. sources within polygons, Fig. 2) were pooled according to ecological categories: $\mathrm{C}_{3}$ saltmarsh angiosperms (Salicornia sp. and Halimione portulacoides), $\mathrm{C}_{4}$ shore angiosperms (Spartina sp.), macroalgae (Fucus serratus, Fucus vesiculosus and/or Enteromorpha sp.), marine POM and benthic diatoms. 
The $\delta^{13} \mathrm{C}$ values indicated a dominance of the latter 4 sources. However, the macroalgae and $\mathrm{C}_{4}$ angiosperms were not isotopically distinct, because the total $\mathrm{NND}^{2}$ of their carbon and nitrogen isotope values was less than 0.1 . Hence, 4 end-members (Table 1) were used in diet contribution estimations: macroalgae and $\mathrm{C}_{4}$ angiosperms, $\mathrm{C}_{3}$ angiosperms, marine POM and benthic diatoms. They presented distinct $\left(\mathrm{NND}^{2}>0.1\right)$ and significantly different (Kruskal-Wallis: $\mathrm{p}<0.001$ ) isotopic compositions.

\section{End-member elemental content and dietary contributions}

End-members implicated in both diets differed in elemental content (Table 1). The plant sources of the present study were typically low in N. Benthic diatoms and phytoplankton exhibited the lowest C:N ratios (5.6 and 7.2 respectively), whereas the highest ratios were observed in macroalgae- $\mathrm{C}_{4}$ angiosperms (15.2 to 19.4). The C:N ratios of benthic diatoms and phytoplankton were similar to the published values of diatom mats and plankton (Abed-Navandi \& Dworschak 2005) on which we based our calculation of carbon and nitrogen content (see 'Materials and methods').

The IsoSource program assumes similar carbon and nitrogen concentrations and equal digestibility of each end-member (Newsome et al. 2004). Because we were interested in elucidating ecological relationships (food proportions ingested), 2 potential error sources were evident in our dietary contribution estimations: the different proportions of $\mathrm{C}$ and $\mathrm{N}$ in microalgae and plant detritus, and the potential differential assimilation of these sources (which contain different amounts of refractory carbon). However, combined use of IsoSource and of the elemental concentration-dependent model allowed us to estimate the extreme feasible contributions of end-members according to 2 alternate scenarios.

(1) The elemental assimilation efficiencies of both Crepidula fornicata and Crassostrea gigas were similar for microalgae and plant detritus; hence, it was necessary to distinguish between the $\mathrm{C}$ and $\mathrm{N}$ content of these sources. The biomasses ingested from the 4 endmembers were therefore estimated by the elemental concentration-dependent model.

(2) The elemental assimilation efficiencies of both species were lower for plant detritus than for microalgae (as might occur if putatively high plant refractory carbon was poorly-assimilated). Even if the $\mathrm{C}$ and $\mathrm{N}$ content of these sources differed, similar $\mathrm{C}$ and $\mathrm{N}$ concentrations could be assimilated. The biomasses ingested from the 4 end-members were therefore estimated using the IsoSource model.
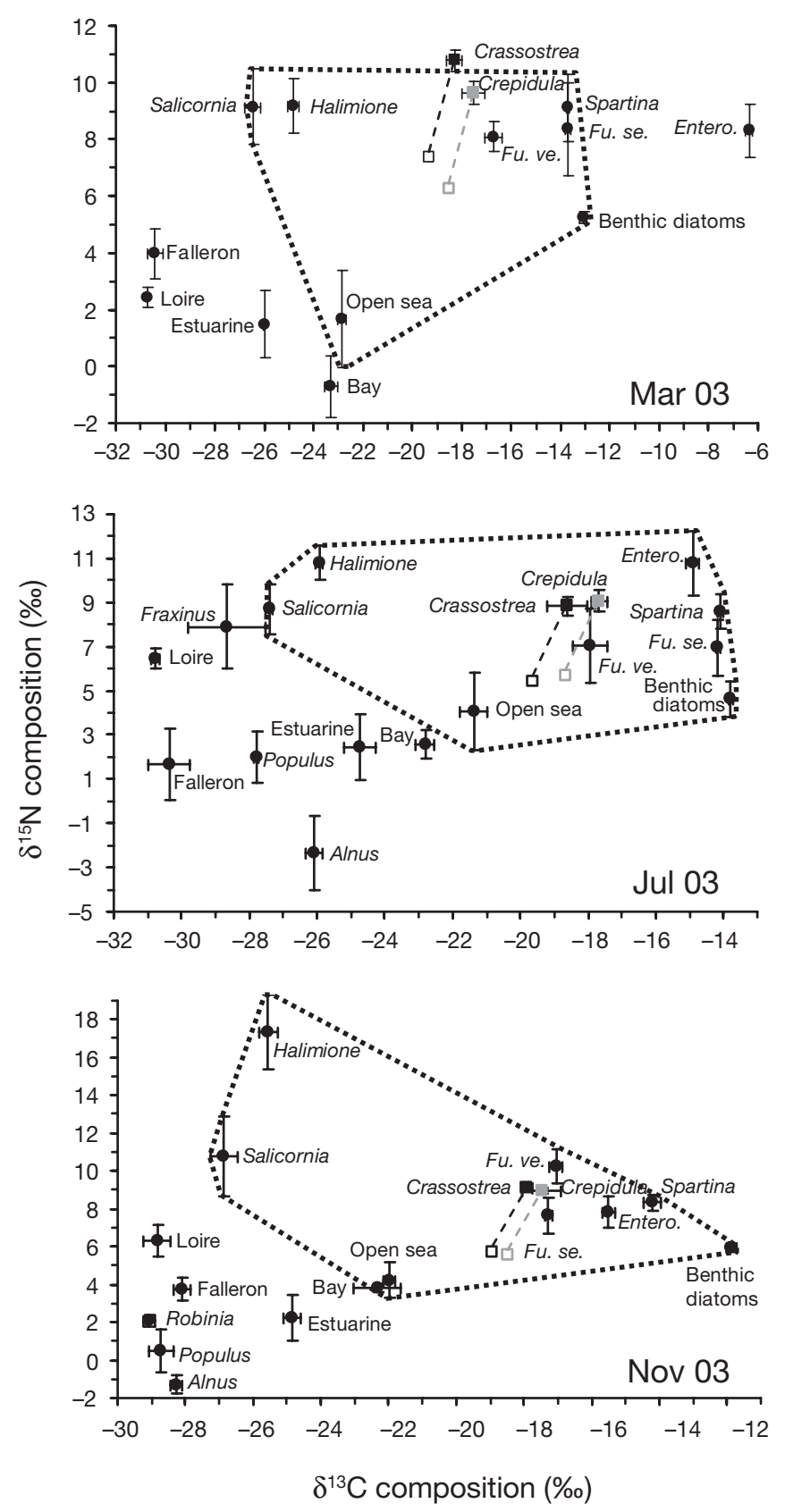

Fig. 2. Dual $\delta^{13} \mathrm{C}$ and $\delta^{15} \mathrm{~N}$ isotopic compositions (mean \%o \pm $\mathrm{SD})$ of 2 suspension-feeders $(\boldsymbol{\bullet},)^{-}$and food sources $(\bullet)$ in March, July and November $2003 ; \delta^{13} \mathrm{C}$ and $\delta^{15} \mathrm{~N}$ values of calculated diets $(\square, \square)$ of Crepidula fornicata (grey) and Crassostrea gigas (black) were determined by subtracting trophic enrichments (dashed lines) of 1 and $3.4 \%$, respectively, from $\delta^{13} \mathrm{C}$ and $\delta^{15} \mathrm{~N}$ values of both species. Dotted polygons delimit sources implicated in the dietary mixture; these sources are pooled to constitute 4 end-members in subsequent analyses. Entero.: Enteromorpha sp.; Fu. se.: Fucus serratus; Fu. ve.: Fucus vesiculosus. POM samples are: Falleron, Loire (freshwater), estuarine, bay (brackish) and open sea. Enteromorpha sp. was discarded from the mixing polygon in March 2003 owing to extreme carbon deviation, which disagreed with other macroalgae and with values from the other 2 sampling events and from previous studies 
IsoSource mixing model

For each end-member on each sampling date, IsoSource provided distributions of feasible contribution ranges to the 2 consumer diets (Fig. 3). The distributions were quite dispersed and included zero contributions in most cases. Nevertheless, dietary proportions differed among sampling dates. The greatest ranges of feasible end-member contributions were observed in March 2003, whereas the smallest ranges were found in November 2003, especially for marine POM and $\mathrm{C}_{3}$ angiosperms. Both suspensionfeeders consumed more phytoplankton in November than in March (50 to $61 \%$ vs. 0 to $36 \%$ ). At the same time, Crassostrea gigas and Crepidula fornicata ingested lower macrophyte proportions (0 to $37 \%$ vs. 0 to $59 \%$, and 0 to $12 \%$ vs. 6 to $50 \%$, respectively, for macroalgae- $\mathrm{C}_{4}$ angiosperms and $\mathrm{C}_{3}$ angiosperms). Thus, phytoplankton contributed 52 to $61 \%$ to the diet of oysters and 50 to $59 \%$ to the diet of slipper limpets in November, whereas 0 to $22 \%$ and 7 to $36 \%$ were assimilated by the 2 species, respectively, in March 2003. $\mathrm{C}_{3}$ angiosperms represented 0 to $12 \%$ of the diet of oysters and 0 to $10 \%$ of the diet of slipper limpets in November, compared with 24 to $50 \%$ and 7 to $37 \%$ in March. In July, intermediate ranges were observed for both species. The significant difference in isotope compositions between C. gigas and C. fornicata in March and July thus appeared to be a result of differential utilization of macrophytes and phytoplankton. The major food source of both species was microalgae (marine phytoplankton and microphytobenthos) in July and November 2003 (but to a lesser extent for slipper limpets in July).

In contrast to the depiction provided in Fig. 3, bivariate graph matrices (Phillips \& Gregg 2003; see Fig. 5) allowed us to examine all feasible end-member contribution combinations. As the contributions summed to $100 \%$, the contribution of 1 trophic source constrains the possible contributions of other sources. Approximately $92 \%$ of feasible sets of solutions implicated 4 sources in all simulations, i.e. the trophic niches of both species overlapped for 4 food resources. In March, only 16 and $15 \%$ of feasible combinations made identical contributions to both species' diets: benthic diatoms and macroalgae- $\mathrm{C}_{4}$ angiosperms, and marine POM and $\mathrm{C}_{3}$ angiosperms respectively. In November, higher overlaps were observed: up to $40 \%$ of feasible combinations contributed equally to slipper limpet and oyster diets. However, no combination showed more than 2 identical percent contributions between diets of either species.
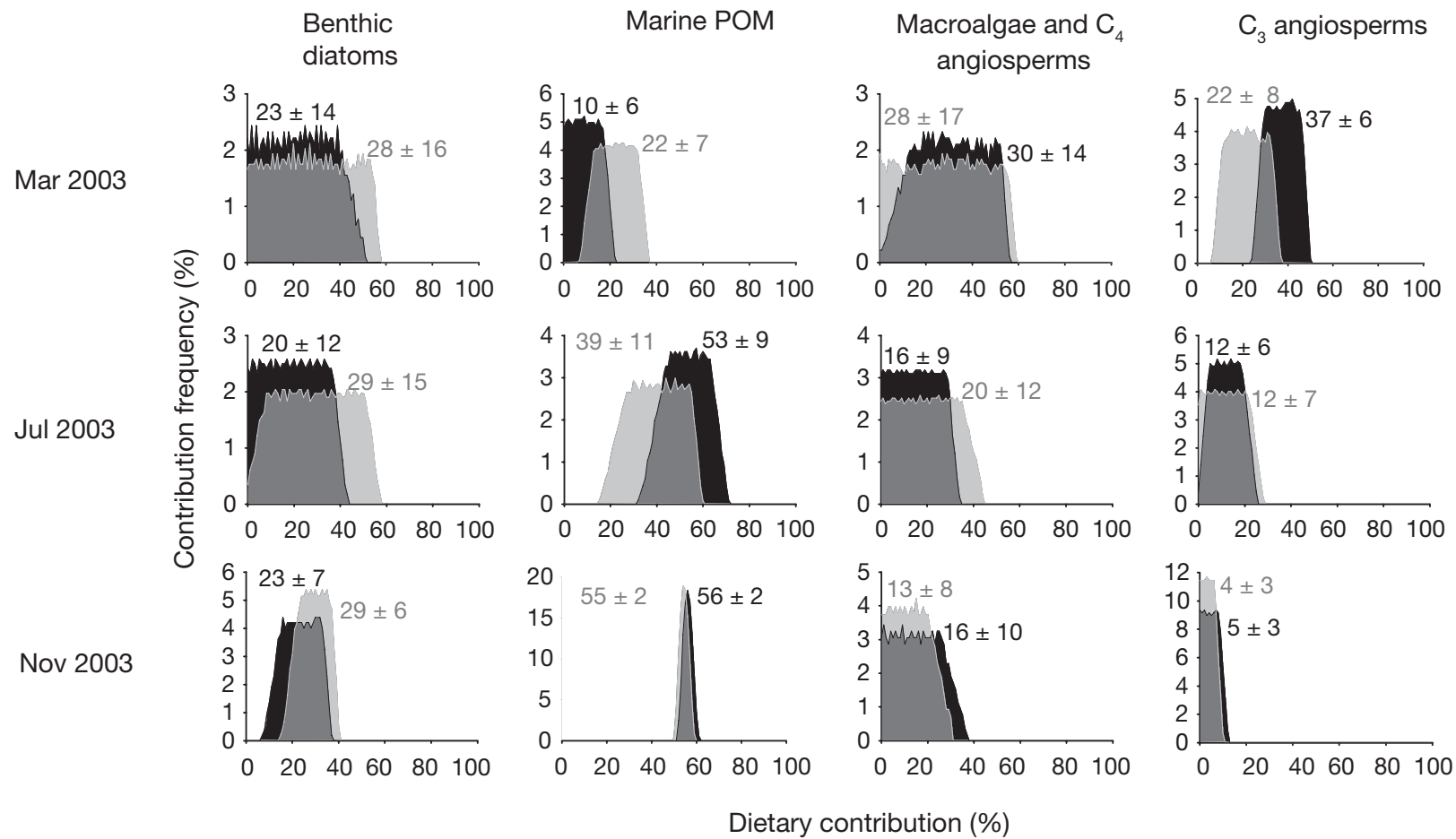

Fig. 3. Distribution of feasible end-member contributions to the diets of Crassostrea gigas (black shaded areas) and Crepidula fornicata (light grey shaded areas) calculated using IsoSource. Mid-grey shading represents overlapping areas. Mean $(\% \pm \mathrm{SD})$ contributions are indicated 
Elemental concentrationdependent program

The concentration-dependent model (Figs. 4 \& 5) gave larger ranges of feasible microalgae contributions and smaller ranges of $\mathrm{C}_{3}$ angiosperm contributions to Crepidula fornicata and Crassostrea gigas diets. The tissue production of these 2 species may thus derive more from benthic diatoms than was estimated by the IsoSource program. $\mathrm{C}_{3}$ angiosperms contributed 20 to $36 \%$ and 10 to $22 \%$ to the diet of oysters and slipper limpets, respectively, in March 2003; Crepidula fornicata appeared to derive its biomass mainly from microalgae, whereas Crassostrea gigas depended more on macrophytes.

Feasible combinations (Fig. 5) of oyster and slipper limpet diets were more similar in March and July than estimated by IsoSource. However, as noted above for the IsoSource estimations, the concentration-dependent model did not estimate more than 2 identical percent contributions in dietary combinations to either species. Four sources also contributed up to $90 \%$ to feasible sets of dietary solutions, i.e. the trophic niches of both species overlapped for all 4 sources using this concentration-dependent program, as was observed using IsoSource.

\section{Characteristics of trophic niches}

Using results from IsoSource, Levins' standardized niche breadth of Crepidula fornicata was wider than that of Crassostrea gigas in March and July 2003. Calculated slipper limpet niche breadth varied from 0.50 to 0.98 , whereas that of oysters varied between 0.51 and 0.81. From March 2003 onwards, the 2 mollusks displayed a progressive reduction in niche breadth attaining the same minimal value in November $(\sim 0.5)$ Over the same period, Pianka's measure exhibited a progressively increasing niche overlap, from 92 to $99 \%$ (Fig. 6). The niche breadths of Crepidula fornicata and Crassostrea gigas calculated from the concentrationdependent model were more similar, showing the same reduction from March to November. Niche overlap was also slightly greater in July and November.

\section{DISCUSSION}

\section{Food sources of Crassostrea gigas and Crepidula fornicata}

The food supply available to suspension-feeders in mudflat ecosystems such as Bourgneuf Bay is conven-
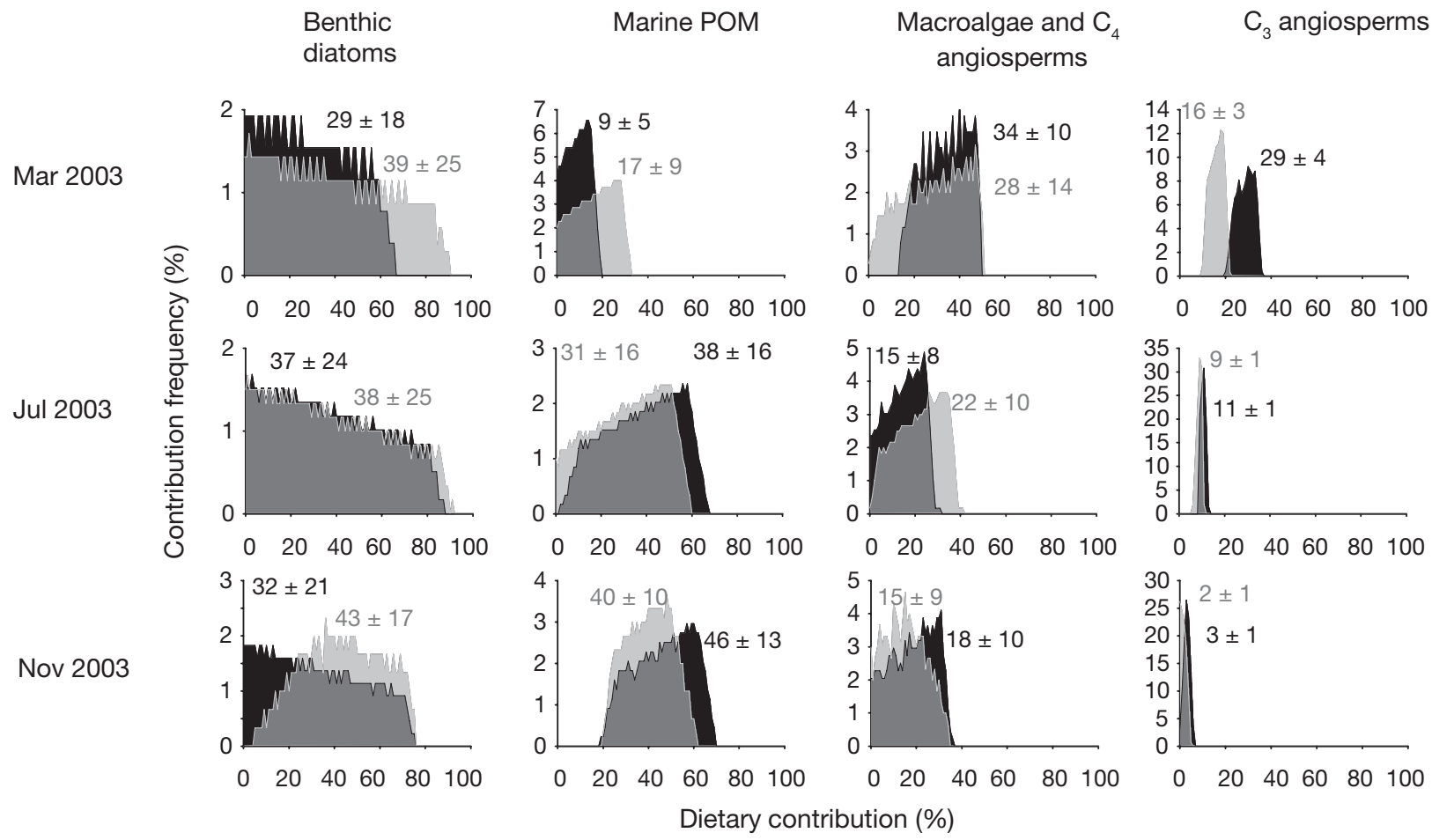

Fig. 4. Distribution of feasible end-member contributions to the diets of Crassostrea gigas (black shaded areas) and Crepidula fornicata (light grey shaded areas) satisfying concentration-dependent conditions. Mid-grey shading represents overlapping areas. Mean $(\% \pm \mathrm{SD})$ contributions are indicated 

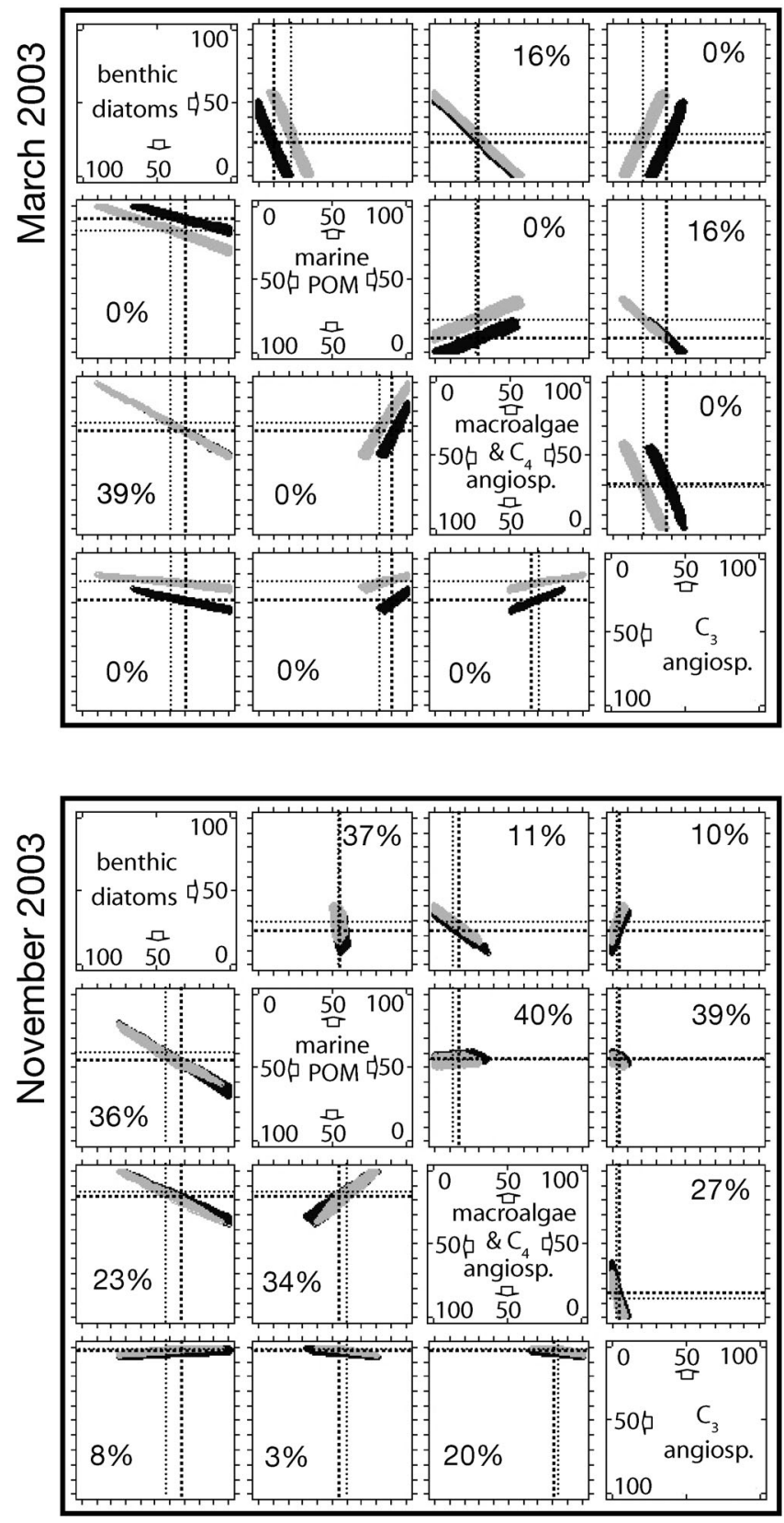

tionally considered to be chiefly composed of benthic diatoms (Riera \& Richard 1996, Leguerrier et al. 2003). However, our comparison of isotopic compositions of the potential food sources and tissues of Crepidula fornicata and Crassostrea gigas revealed that 4 primary production sources were predominantly assimilated: suspended POM (essentially phytoplankton; up to $70 \%$ ), benthic diatoms (up to $90 \%$ ), angiosperms and macroalgae (up to $60 \%$ ). The relative contribution of each component differed according to sampling date (more markedly for oysters): macrophytes were more important in March 2003, and microalgae (phytoplank-

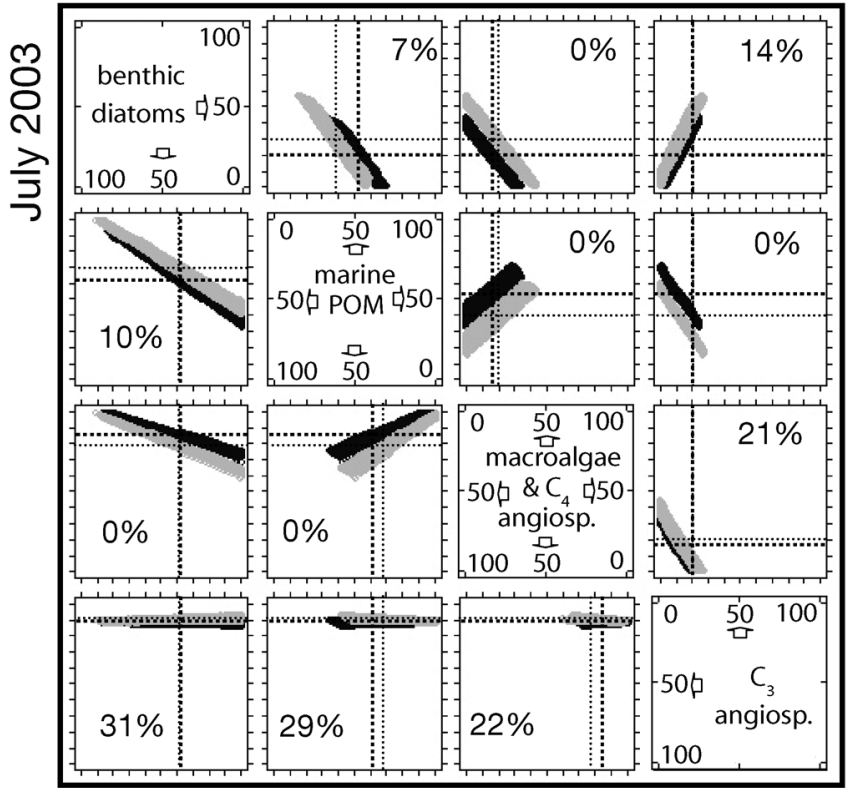

Fig. 5. Bivariate graph matrices showing contributions (\%) of 4 end-members for all feasible dietary combinations in March, July and November 2003. Black shading indicates contributions to diets of Crassostrea gigas and grey shading indicates contributions to Crepidula fornicata; where they intersect, grey surfaces are superimposed on black surfaces. Graphs above the diagonal separation show IsoSource results, whereas those below the diagonal panels show feasible combinations calculated from the concentration-dependent model. Thick and fine dotted lines show contribution means for oysters and slipper limpets respectively; \% of contributions common to both species' diets are given in each panel

ton and benthic diatoms) became more important in July and November.

Diets can also differ qualitatively despite a high degree of similarity in natural isotope deviations (e.g. Carman \& Fry 2002). Slipper limpets and oysters may ingest different species or sizes of microalgae; indeed, the differential selective capability of these 2 species (Beninger et al. 2007, this volume) makes this highly probable. Complementary stomach content analyses would help to elucidate this particular aspect.

The $\delta^{13} \mathrm{C}$ and $\delta^{15} \mathrm{~N}$ deviations of oysters from Bourgneuf Bay extended further beyond those of benthic diatom, especially in March, compared with oysters of the previously-studied Marennes-Oléron site (also on the French Atlantic coast) that presented a diet primarily based on microphytobenthos (Fig. 7; Riera \& Richard 1996, Riera 1998). In addition, the difference between isotopic deviations of oysters or slipper limpets and benthic diatoms was greater in Bourgneuf Bay than in Oosterschelde (Fig. 7; Riera et al. 2002). Nonetheless, benthic diatoms feasibly contributed a substantial portion to the diets of Crepidula fornicata 


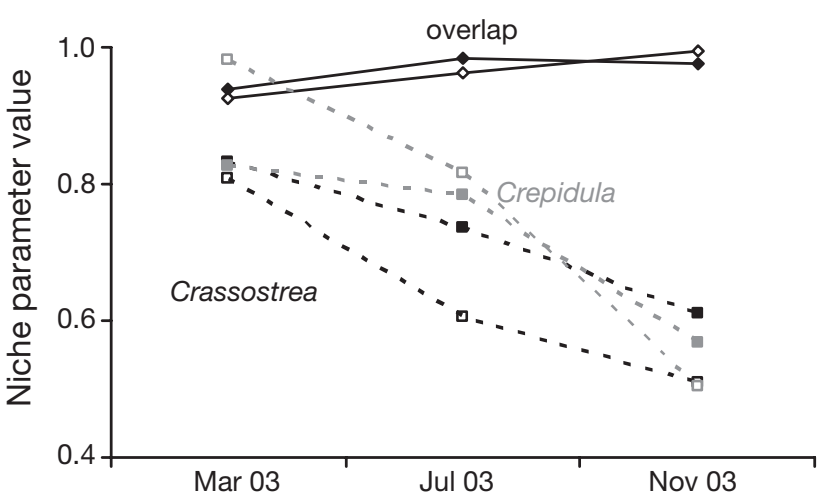

Fig. 6. Levins' standardized niche breadth (dashed lines) of Crepidula fornicata (grey) and Crassostrea gigas (black), and Pianka's measure of niche overlap between both species (continuous line); obtained from IsoSource (filled symbols) and concentration-dependent model (open symbols) simulations toral seaweed beds of unknown extent exist at the entry to the bay (Y. Gruet, Universite de Nantes, pers. comm.). Relatively long residence times in Bourgneuf Bay (approx. 2 mo) facilitates physico-chemical and biological modification of detritus particles in the water column.

The estimations of end-member dietary contributions suggested that macroalgae and $\mathrm{C}_{4}$ angiosperms contributed more than $\mathrm{C}_{3}$ angiosperms to Crepidula fornicata and Crassostrea gigas diets, even though $\mathrm{C}_{3}$ plants predominate in saltmarshes of the French Atlantic coast (European Natura 2000 code 1330; http://natura2000.environnement.gouv.fr/habitats/ HAB1330.html). Suspension-feeders obtain maximum benefit from plant detritus in earlier stages of decomposition, before most of the nutrient and energy-rich compounds are used by microheterotrophs (Stuart 1982). Although trophic mediation through bacteria or and Crassostrea gigas on all 3 sampling occasions (Figs. $3 \& 4$ ). Microphytobenthos, which has an organic composition more readily assimilated than that of angiosperms, may be a major food source to secondary producers (e.g. Currin et al. 1995, Kang et al. 2003).

Phytoplankton was also an important component of the diets of both suspension-feeders. Concomitant grazing on resuspended microphytobenthos and phytoplankton is well documented for intertidal suspension-feeders (e.g. Kang et al. 1999, Rossi et al. 2004). Phytoplankton variability is thus a determinant of individual and population bivalve dynamics in the field (Grant 1996).

Stable isotope compositions of Crassostrea gigas and Crepidula fornicata in Bourgneuf Bay, together with mixing model analyses, indicated a generally high input by angiosperms and macroalgae. Suspended, variably degraded plant detritus has been shown to be a major trophic substrate for coastal secondary producers, including suspension-feeders, in American saltmarsh food webs (e.g. Currin et al. 1995, Deegan \& Garritt 1997). Our Crepidula fornicata and Crassostrea gigas sampling site, La Couplasse, is close to a total of 9.34 ha of saltmarsh composed of Halimione portulacoides, Salicornia sp. and Spartina sp., and is adjacent to 234.8 ha of macroalgal cover. In addition, infralit-

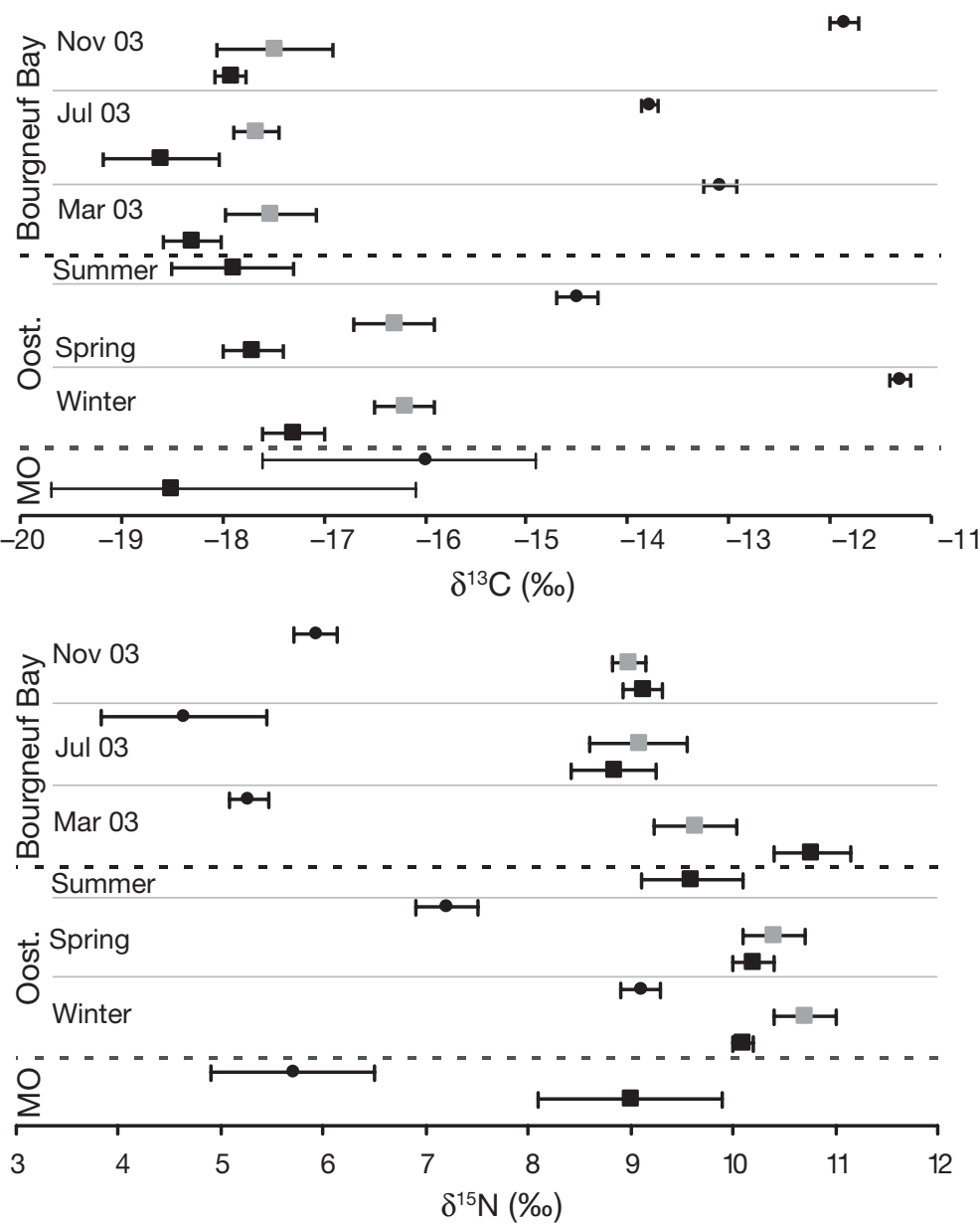

Fig. 7. Mean $\delta^{13} \mathrm{C}$ and $\delta^{15} \mathrm{~N}$ of Crassostrea gigas ( $\left.\mathbf{\square}\right)$, Crepidula fornicata (n) and benthic diatoms (-) measured in Bourgneuf Bay (France; present study), the Oosterschelde ('Oost.', The Netherlands; Riera et al. 2002) and MarennesOléron Bay ('MO', France; Riera \& Richard 1996, Riera 1998). Error bars are either SD or ranges of mean $\delta^{13} \mathrm{C}$ from MO. Dashed lines separate locations; grey solid lines separate seasons or months for which data was collected 
microzooplankton is often necessary for the digestion of angiosperm tissues (Mann 1988, Langdon \& Newell 1990, Riera 1998), no such mediation was observed in the suspension-feeders of the present study: $\delta^{15} \mathrm{~N}$ values indicated no corresponding trace of enrichment.

In contrast, macroalgal tissues contain relatively large amounts of nitrogen, protein and energy that is readily assimilated by primary consumers (Mann 1988, Bowen et al. 1995); these tissues also constitute a significant source of nutrient-rich detritus, used by suspension-feeders as sources of carbon and nitrogen throughout the year (Bustamante \& Branch 1996). In the present study, an increased contribution by plant detritus was observed in March 2003 (i.e. winter assimilation), when microalgal production is minimal. It is thus possible that these suspension-feeders exploit the increased proportion of plant detritus in the winter period, as has been previously reported for other suspension-feeding bivalves (Lucas et al. 1987, Cranford \& Grant 1990).

Direct assimilation of plant tissues by oysters and slipper limpets depends on the variety and nature of their digestive enzymes. The extracellular digestive enzymes of bivalves, including oysters, comprise especially cellulases, amylases and laminarinases (Brock et al. 1986). Oysters are thus capable of degrading the major organic components present in detritus (Newell \& Langdon 1986). In particular, Crassostrea virginica assimilates significant amounts of saltmarsh angiosperm carbon (Newell \& Langdon 1986, Langdon \& Newell 1990).

\section{Advantages of combined use of IsoSource and concentration-dependent models}

Previous stable isotope studies of suspension-feeder diets either did not estimate relative contributions, or quantified source contributions using simple mixing equations in which no more than 2 sources were implicated (Riera et al. 1999, Page \& Lastra 2003). We used IsoSource-type linear mixing models to statistically define the feasible relative contributions of endmembers to the diets of these 2 suspension-feeders.

The assimilation of food sources was shown to vary according to mollusk species and source type (Tsikhon-Lukanina 1982). The diverse source types implicated in both Crepidula fornicata and Crassostrea gigas diets could present dissimilar digestible $\mathrm{C}$ and $\mathrm{N}$ fractions, in addition to different elemental content. Although abundant literature exists on the digestibility of food for humans or bears (Koch \& Phillips 2002, Newsome et al. 2004), we are unaware of any such studies on microphage food quality values, and hence the digestibility of the various $\mathrm{C}$ and $\mathrm{N}$ fractions. Our results, obtained by combined use of IsoSource and concentration-dependent models, described most probable overlaps between the diets of Crepidula fornicata and Crassostrea gigas despite the lack of literature on digestibility of the different end-members. Based on the incorporation of $\mathrm{C}$ and $\mathrm{N}$ concentrations, results from the concentration-dependant model indicated a greater similarity in the diets of these 2 species, with a lesser importance of detritus, than did those from the IsoSource model.

\section{Trophic relationships between Crassostrea gigas and Crepidula fornicata}

Given that Crepidula fornicata and Crassostrea gigas both feed on seston and, that in contrast to the oyster (Cognie et al. 2003), C. fornicata does not appear capable of qualitative selection, diet overlap appeared highly probable (Beninger et al. 2007). Isotope comparisons confirmed this assumption: the same food types were ingested on 3 seasonal sampling dates. However, significant differences in the tissue isotope deviations of these 2 species in March and July 2003 revealed that diets differed substantially in winter and spring. Similar conclusions-i.e. same source types but different diets-were reported for these 2 species in the Oosterschelde (The Netherlands; Riera et al. 2002; Fig. 7). In comparison with our study, the dietary differences of specimens from the Oosterschelde were consistently more pronounced, especially with respect to carbon deviations. However, substantial ingestion of macrophyte detritus by these suspension-feeders has not been previously reported from other European Atlantic sites (Oosterschelde and Marennes-Oléron). Interestingly, this corresponds to reduced presence of macrophytes at these sites (Riera \& Richard 1996, Riera et al. 2002). These observations bring to attention the need for site-specific diet studies of these invasive species, in order to obtain a realistic understanding of their feeding biology in European coastal ecosystems.

The trophic niche breadth of slipper limpets was either similar to or broader than that of Pacific oysters, indicating that Crepidula fornicata is a more generalist suspension-feeder than Crassostrea gigas. This may be due, at least in part, to their different capacities for qualitative selective feeding (Beninger et al. 2007). On all 3 sampling dates of the present study, the trophic niches of Crepidula fornicata and Crassostrea gigas overlapped to variable degrees in Bourgneuf Bay, with greater overlap in November when niche breadths were narrower. This high degree of overlap (consistently $>90 \%$ ) emphasizes the potential for trophic competition between these 2 invasive species; how- 
ever, competition can only be demonstrated when resources are limiting for both species. In the absence of complete source data and functional ecosystem models, demonstration of actual competition must therefore rely on specific physiological and isotopic indices (e.g. shifts in filtration, use of specific diet components). The findings of the present study show that the characteristics of trophic overlap/competition between Crepidula fornicata and Crassostrea gigas are likely to be highly variable throughout their sympatric range, depending on types and abundances of local food sources.

Acknowledgements. We thank S. Derrien for performing mass spectrometry of prepared samples, Dr. D. Phillips for his help with mixing programs, and Mr. J. L. Decottignies for his skilled dexterity in the construction of a sampling apparatus. We are extremely grateful to Mr. A. Lamour and crew for open-sea sampling aboard the SNSM vessel 'Georges Clemenceau II'.

\section{LITERATURE CITED}

Abed-Navandi D, Dworschak PC (2005) Food sources of tropical thalassinidean shrimps: a stable-isotope study. Mar Ecol Prog Ser 291:159-168

Barillé-Boyer AL, Haure J, Baud JP (1997) L'ostréiculture en baie de Bourgneuf. Relation entre la croissance des huîtres Crassostrea gigas et le milieu naturel : synthèse de 1986 à 1995. Report No. DRV/RA/RST/97/Num, IFREMER

Barillé L, Cognie B, Beninger PG, Decottignies P, Rincé Y (2006) Feeding responses of the gastropod Crepidula fornicata to changes in seston concentration. Mar Ecol Prog Ser 322:169-178

Beninger PG, Decottignies P, Guiheneuf F, Barillé L, Rincé Y (2007) Comparison of particle processing by two introduced suspension feeders: selection in Crepidula fornicata and Crassostrea gigas. Mar Ecol Prog Ser 334: 165-177

Blanchard M (1997) Spread of the slipper limpet Crepidula fornicata (L. 1758) in Europe. Current state and consequences. Sci Mar 61:109-118

Bowen SH, Lutz EV, Ahlgren MO (1995) Dietary protein and energy as determinants of food quality: trophic strategies compared. Ecology 76:899-907

Brock V, Kennedy VS, Brock A (1986) Temperature dependency of carbohydrase activity in the hepatopancreas of thirteen estuarine and coastal bivalve species from the North American east coast. J Exp Mar Biol Ecol 103: 87-101

Bustamante RH, Branch GM (1996) The dependence of intertidal consumers on kelp-derived organic matter on the west coast of South Africa. J Exp Mar Biol Ecol 196:1-28

Carman KR, Fry B (2002) Small-sample methods for $\delta^{13} \mathrm{C}$ and $\delta^{15} \mathrm{~N}$ analysis of the diets of marsh meiofaunal species using natural-abundance and tracer-addition isotope techniques. Mar Ecol Prog Ser 240:85-92

Chauvaud L, Jean F, Ragueneau O, Thouzeau G (2000) Longterm variation of the Bay of Brest ecosystem: benthicpelagic coupling revisited. Mar Ecol Prog Ser 200:35-48

Cognie B, Barillé L, Massé G, Beninger PG (2003) Selection and processing of large suspended algae in the oyster
Crassostrea gigas. Mar Ecol Prog Ser 250:145-152

Cole HA, Hancock DA (1956) Progress in oyster research in Britain 1949-1954, with special references to the control of pests and diseases. Cons Int Explor Mer Rapp Proc Verb 140:24-29

Cranford PJ, Grant J (1990) Particle clearance and absorption of phytoplankton and detritus by the sea scallop Placopecten magellanicus (Gmelin). J Exp Mar Biol Ecol 137: 105-121

Créach V, Schricke MT, Bertru G, Mariotti A (1997) Stable isotopes and gut analyses to determine feeding relationships in saltmarsh macroconsumers. Estuar Coast Shelf Sci 44:599-611

Currin CA, Newell SY, Paerl HW (1995) The role of standing dead Spartina alterniflora and benthic microalgae in salt marsh food webs: considerations based on multiple stable isotope analysis. Mar Ecol Prog Ser 121:99-116

Davis MA, Thompson K (2000) Eight ways to be a colonizer; two ways to be an invader: a proposed nomenclature scheme for invasion ecology. Bull Ecol Soc Am 81:226-230

Deegan LA, Garritt RH (1997) Evidence for spatial variability in estuarine food webs. Mar Ecol Prog Ser 147:31-47

de Montaudouin X, Audemard C, Labourg PJ (1999) Does the slipper limpet (Crepidula fornicata, L.) impair oyster growth and zoobenthos biodiversity? A revisited hypothesis. J Exp Mar Biol Ecol 235:105-124

DeNiro MJ, Epstein S (1978) Influence of diet on the distribution of carbon isotopes in animals. Geochim Cosmochim Acta 42:495-506

Ehrhold A, Blanchard M, Auffret JP, Garlan T (1998) The role of Crepidula proliferation in the modification of the sedimentary tidal environment in Mont-Saint-Michel Bay (The Channel, France). CR Acad Sci Paris 327:583-588

Gannes LZ, O'Brien DM, Martínez del Rio C (1997) Stable isotopes in animal ecology: assumptions, caveats, and a call for more laboratory experiments. Ecology 78:1271-1276

Grant J (1996) The relationship of bioenergetics and the environment to the field growth of cultured bivalves. J Exp Mar Biol Ecol 200:239-256

Grosholz E (2002) Ecological and evolutionary consequences of coastal invasions. Trends Ecol Evol 17:22-27

Heip CHR, Goosen NK, Herman PMJ, Kromkamp J, Middelburg JJ, Soetaert K (1995) Production and consumption of biological particles in temperate tidal estuaries. Oceanogr Mar Biol Ann Rev 33:1-149

Hsieh HL, Kao WY, Chen CP, Liu PJ (2000) Detrital flows through the feeding pathway of the oyster (Crassostrea gigas) in a tropical shallow lagoon: $\delta^{13} \mathrm{C}$ signals. Mar Biol 136:677-684

Kang CK, Sauriau PG, Richard P, Blanchard GF (1999) Food sources of the infaunal suspension-feeding bivalve Cerastoderma edule in a muddy sandflat of Marennes-Oléron Bay, as determined by analyses of carbon and nitrogen stable isotopes. Mar Ecol Prog Ser 187:147-158

Kang CK, Kim JB, Lee KS, Kim JB, Lee PY, Hong JS (2003) Trophic importance of benthic microalgae to macrozoobenthos in coastal bay systems in Korea: dual stable C and N isotope analyses. Mar Ecol Prog Ser 259:79-92

Koch PA, Phillips DL (2002) Incorporating concentration dependence in stable isotope mixing models: a reply to Robbins, Hilderbrand and Farley (2002). Oecologia 133: 14-18

Korringa P (1951) Crepidula fornicata as an oyster-pest. Cons Int Explor Mer Rapp Proc Verb 128:55-59

Krebs CJ (1999) Ecological methodology. Benjamin Cummings, Menlo Park, CA

Langdon CJ, Newell RIE (1990) Utilization of detritus and 
bacteria as food sources by two bivalve suspension-feeders, the oyster Crassostrea virginica and the mussel Geukensia demissa. Mar Ecol Prog Ser 58:299-310

Leguerrier D, Niquil N, Boileau N, Rzeznik J, Sauriau PG, Le Moine O, Bacher C (2003) Numerical analysis of the food web of an intertidal mudflat ecosystem on the Atlantic coast of France. Mar Ecol Prog Ser 246:17-37

Le Pape O, Guérault D, Désaunay Y (2004) Effect of an invasive mollusc, American slipper limpet Crepidula fornicata, on habitat suitability for juvenile common sole Solea solea in the Bay of Biscay. Mar Ecol Prog Ser 277:107-115

Lubetkin SC, Simenstad CA (2004) Multi-source mixing models to quantify food web sources and pathways. J Appl Ecol 41:996-1008

Lucas MI, Newell RC, Shumway SE, Seiderer LJ, Bally R (1987) Particle clearance and yield in relation to bacterioplankton and suspended particulate availability in estuarine and open coast populations of the mussel Mytilus edulis. Mar Ecol Prog Ser 36:215-224

Mann KH (1988) Production and use of detritus in various freshwater, estuarine, and coastal marine ecosystems. Limnol Oceanogr 33:910-930

McCutchan JHJ, Lewis WMJ, Kendall C, McGrath CC (2003) Variation in trophic shift for stable isotope ratios of carbon, nitrogen, and sulfur. Oikos 102:378-390

Méléder V, Launeau P, Barillé L, Rincé Y (2003) Cartographie des peuplements du microphytobenthos par télédétection visible-infrarouge dans un écosystème conchylicole. CR Biol 326:377-389

Mitbavkar S, Anil AC (2004) Vertical migratory rhythms of benthic diatoms in a tropical intertidal sand flat: influence and tides. Mar Biol 145:9-20

Newell RIE, Langdon CJ (1986) Digestion and absorption of refractory carbon from the plant Spartina alterniflora by the oyster Crassostrea virginica. Mar Ecol Prog Ser 34: 105-115

Newsome SD, Phillips DL, Culleton BJ, Guilderson TP, Koch PL (2004) Dietary reconstruction of an early to middle Holocene human population from the central California coast: insights from advanced stable isotope mixing models. J Archaeol Sci 31:1101-1115

Orton JH (1912) The mode of feeding of Crepidula, with an account of the current-producing mechanism in the mantle cavity, and some remarks on the mode of feeding in Gastropods and Lamellibranchs. J Mar Biol Assoc UK New Series 9:444-478

Page HM, Lastra M (2003) Diet of intertidal bivalves in the Ría de Arosa (NW Spain): evidence from stable C and N isotope analysis. Mar Biol 143:519-532

Phillips DL, Gregg JW (2003) Source partitioning using stable isotopes: coping with too many sources. Oecologia 136: 261-269

Editorial responsibility: Otto Kinne (Editor-in-Chief), Oldendorf/Luhe, Germany
Post DM (2002) Using stable isotopes to estimate trophic position: models, methods, and assumptions. Ecology 83: 703-718

R Development Core Team (2005) R: a language and environment for statistical computing. R Foundation for Statistical Computing, Vienna

Riera P (1998) $\delta^{15} \mathrm{~N}$ of organic matter sources and benthic invertebrates along an estuarine gradient in MarennesOléron Bay (France): implications for the study of trophic structure. Mar Ecol Prog Ser 166:143-150

Riera P, Richard P (1996) Isotopic determination of food sources of Crassostrea gigas along a trophic gradient in the estuarine bay of Marennes-Oléron. Estuar Coast Shelf Sci 42:347-360

Riera P, Richard P, Grémare A, Blanchard G (1996) Food source of intertidal nematodes in the Bay of MarennesOléron (France), as determined by dual stable isotope analysis. Mar Ecol Prog Ser 142:303-309

Riera P, Stal LJ, Nieuwenhuize J, Richard P, Blanchard G, Gentil F (1999) Determination of food sources for benthic invertebrates in a salt marsh (Aiguillon Bay, France) by carbon and nitrogen stable isotopes: importance of locally produced sources. Mar Ecol Prog Ser 187:301-307

Riera P, Stal LJ, Nieuwenhuize J (2002) $\delta^{13} \mathrm{C}$ versus $\delta^{15} \mathrm{~N}$ of cooccurring molluscs within a community dominated by Crassostrea gigas and Crepidula fornicata (Oosterschelde, The Netherlands). Mar Ecol Prog Ser 240:291-295

Rossi F, Herman PMJ, Middelburg JJ (2004) Interspecific and intraspecific variation of $\delta^{13} \mathrm{C}$ and $\delta^{15} \mathrm{~N}$ in deposit- and suspension-feeding bivalves (Macoma balthica and Cerastoderma edule): evidence of ontogenic changes in feeding mode of Macoma balthica. Limnol Oceanogr 49:408-414

Ruesink JL, Lenihan HS, Trimble AC, Heiman KW, Micheli F, Byers JE, Kay MC (2005) Introduction of non-native oysters: ecosystem effects and restoration implications. Annu Rev Ecol Evol Syst 36:643-689

Sarà G, Vizzini S, Mazzola A (2003) Sources of carbon and dietary habits of new Lessepsian entry Brachidontes pharaonis (Bivalvia, Mytilidae) in the western Mediterranean. Mar Biol 143:713-722

Stuart V (1982) Absorbed ration, respiratory costs and resultant scope for growth in the mussel Aulacomya ater (Molina) fed on a diet of kelp detritus of different ages. Mar Biol Lett 3:289-306

Tsikhon-Lukanina YA (1982) Food assimilability in bottom mollusks. Oceanology 22:619-622

Wada E, Hattori A (1991) Nitrogen in the sea: forms, abundances, and processes. CRC Press, Boca Raton, FL

Yokoyama H, Tamaki A, Harada K, Shimoda K, Koyama K, Ishihi Y (2005) Variability of diet-tissue isotopic fractionation in estuarine macrobenthos. Mar Ecol Prog Ser 296: $115-128$

Submitted: April 19, 2004; Accepted: July 11, 2005

Proofs received from author(s): March 13, 2007 